\title{
Cellular Component of Vascular Calcification
}

\author{
Fibroblasts Are Essential for Calcium Deposition in Cultured Cells
}

\author{
Y. Watanabea M. Suzukib Y. Oyama ${ }^{b}$ E. Kusano ${ }^{a} \quad$ K. Tamba ${ }^{a}$ O. limura \\ C. Ito ${ }^{a}$ M. Imai ${ }^{b}$ Y. Asano ${ }^{a}$

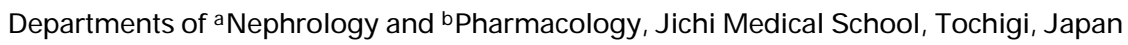

\section{Key Words}

Vascular calcification - Fibroblasts - Smooth muscle cells $\cdot$ von-Kossa $\cdot$ Calcium deposition

\begin{abstract}
It has been reported that calcium deposition and calcium content in cultured human aortic smooth muscle cells (SMC) increased when the cells are incubated in a medium with a high phosphate concentration ( $2 \mathrm{mM})$. To determine the cellular components or soluble factors contributing to the deposition, we cultured commercially available SMC, fibroblasts ( $\mathrm{Fb}$ ) and endothelial cells ( $\mathrm{Ed})$. These cells and their mixtures were incubated for 10 days in normal or high-phosphate media. Calcium crystals were stained by the von-Kossa staining and counted in the defined area. Calcium content was measured by a colorimetric assay. SMC were incubated in high-phosphate media (up to $2 \mathrm{mM}$ ) or $\beta$-glycerophosphate ( $\beta$-GP) media, resulting in no obvious deposition of calcium crystals, irrespective of the coating of type I collagen on the dish. Next, various combinations of cells were cultured, and a significant number of depositions were observed only when $\mathrm{Fb}$ were included in the combination. The calcium content was significantly higher in cultures of SMC and Fb. The calcium deposition on single or mixture of the cells did not increase compared with con-
\end{abstract}

(C) 2002 S. Karger AG, Basel 0028-2766/02/0924-0840\$18.50/0

Fax +41613061234 E-Mail karger@karger.ch www. karger.com
Accessible online at: www.karger.com/journals/nef trol when cells were incubated in a high concentration of phosphate, cultured in the existence of $\beta$-GP or uremic serum. We therefore conclude that $\mathrm{Fb}$, rather than SMC or Ed, are essential for calcium deposition and calcium accumulation in culture. Phosphate concentration in the medium and uremic serum did not influence the deposition of calcium.

Copyright @2002 S. Karger AG, Basel

\section{Introduction}

Vascular calcification in uremic patients is a risk factor for coronary ischemia and cerebral infarction [1]. Until recently, vascular calcification was considered to be a passive degenerative and end-stage process of vascular disease [2-4]. However, bone morphogenetic proteins, including bone morphogenetic protein-2, and noncollagenous bone matrix proteins such as osteopontin, osteonectin, osteocalcin and matrix Gla protein have been found in calcified vascular tissues [5-8]. In addition, it has been demonstrated that vascular cell calcification in vitro was regulated by caliciotropic hormones such as parathyroid hormone-related peptide [9] and vitamin D [10] as well as by lipid oxidation products $[11,12]$. These findings suggest that the process of vascular calcification is similar to that of mineralization in bone, cartilage and teeth and

Makoto Suzuki, MD

Department of Pharmacology, Jichi Medical School

Minamikawachi, Tochigi, 329-0498 (Japan)

Tel. +81 28558 7326, Fax +81 28544 5541, E-Mail macsuz@jichi.ac.jp 
that vascular calcification is in fact an actively regulated process [13]. Because numerous factors contribute to the formation of calcium deposition in cell culture, and it has been needed to find an experimental condition that leads calcium deposition. In a recent study, calcium deposition and an increase in calcium content were found in human aortic SMC cultured in a high-phosphate $(2 \mathrm{mM})$ medium [14]. In addition, it was has been shown that $\beta$-GP accelerates calcification in cultured bovine vascular SMC [15].

However, no results using commercially available human vascular cells have been reported. Cultures of commercially available human cells would enable the identification of the soluble factors that increases the deposition of calcium in patients suffering from metastatic calcification. The present study was therefore designed to determine the culture conditions that would enable reproduction of calcium deposition.

\section{Methods}

\section{Cell Culture}

Ed (\#375 from the human aorta), SMC (\#716 from the human aorta, not containing $\mathrm{Fb}$ ) and $\mathrm{Fb}$ (\#469 from the human fetal lung) were purchased from Applied Cell Biology Res. Inst. (Wash., USA). A kind of cells or their mixtures were cultured in growth medium (CS-C complete medium ${ }^{\mathrm{TM}}$, Cell Systems Corporation, Wash., USA) until they had reached confluence (4th day). The medium was then changed to one containing a high concentration of phosphate (1-2 $\mathrm{m} M)$ or $10 \mathrm{~m} M \beta$-GP. The cells were cultured for further 10 days and were used for the biochemical analysis. To determine whether a matrix of $\mathrm{Fb}$ or living $\mathrm{Fb}$ is required for the deposition, the $\mathrm{Fb}$ were damaged by freezing and thawing in a hypotonic solution (10 $\mathrm{m} M$ phosphate buffer, $27 \mathrm{mosm} / \mathrm{kg}$ ) $(\mathrm{Fb})$. Then the cells, Ed and $/$ or SMC were seeded on them.

Cytochemical and Ultrastructural Analyses

Cell cultures were fixed in pure ethanol for mineral analyses. Mineral depositions were assessed and counted using a light microscope (BX40, Olympus) by von-Kossa staining (VK) (1 h, 5\% silver nitrate).

\section{Quantification of Calcium Deposition}

Cells were decalcified with $0.6 \mathrm{~N} \mathrm{HCl}$ over a period of $24 \mathrm{~h}$. The calcium content of $\mathrm{HCl}$ supernatant was determined colorimetrically by the o-cresolphthalein complexone method (Calcium C-test Wako; Wako Pure Chemical Industries) [16]. After decalcification, the cells were washed three times with phosphate-buffered saline and dissolved in $0.1 \mathrm{~N} \mathrm{NaOH}$ and $0.1 \%$ sodium dodecyl sulfate (SDS). The protein content was measured using a BCA protein assay kit (Pierce, Rockford, Ill., USA). The calcium content of the cell layer was normalized to protein content.

\section{Patients' Sera}

$\mathrm{Fb}$ and $\mathrm{SMC}$ were cultured in CS-C complete medium until they had reached confluence (4th day). The medium was changed into medium (CSC medium formulated without serum) in the presence of 5 or $10 \%$ dialysis patient serum. Serum samples from 10 dialysis patients were combined. The cells were cultured for further 10 days. The medium was replaced with fresh medium every 2 days.

\section{Statistics}

Data were analyzed for statistical significance by ANOVA, and $\mathrm{p}<0.05$, as calculated by Bonferroni's analysis, was considered significant.

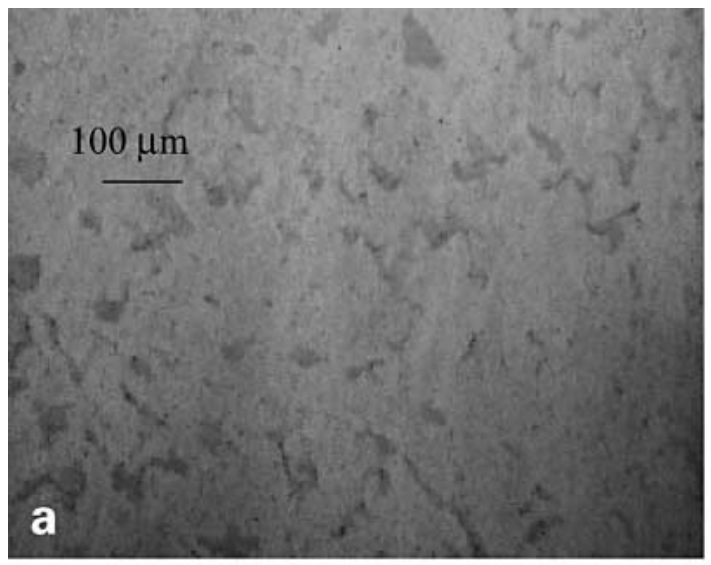

Fibroblast

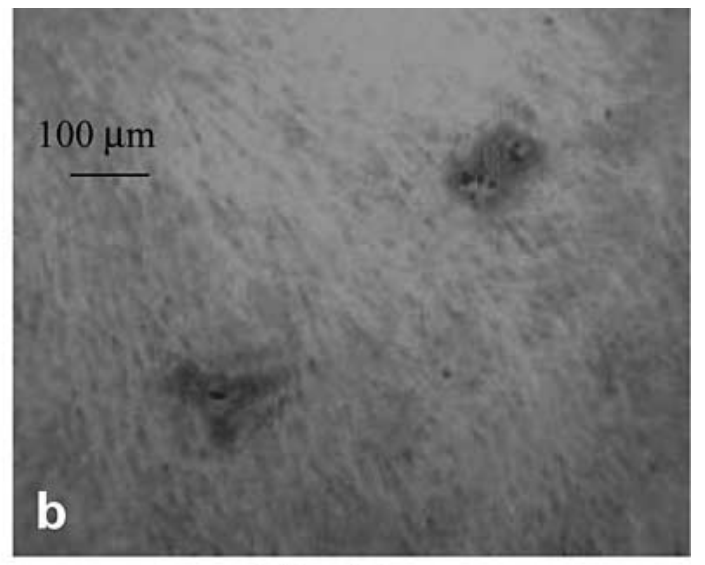

Fibroblast

Fig. 1. Calcification on fibroblasts $(\mathrm{Fb})$. Fb were cultured in growth medium for 10 days. After incubation, they were fixed with ethanol. Deposition of calcium crystals was assessed by von-Kossa staining (VK) at the light microscopic level. a A small deposition (about $20 \mu \mathrm{m}$ ) is shown. b A larger deposition (about $150 \mu \mathrm{m}$ ) is shown. $\times 100$. 


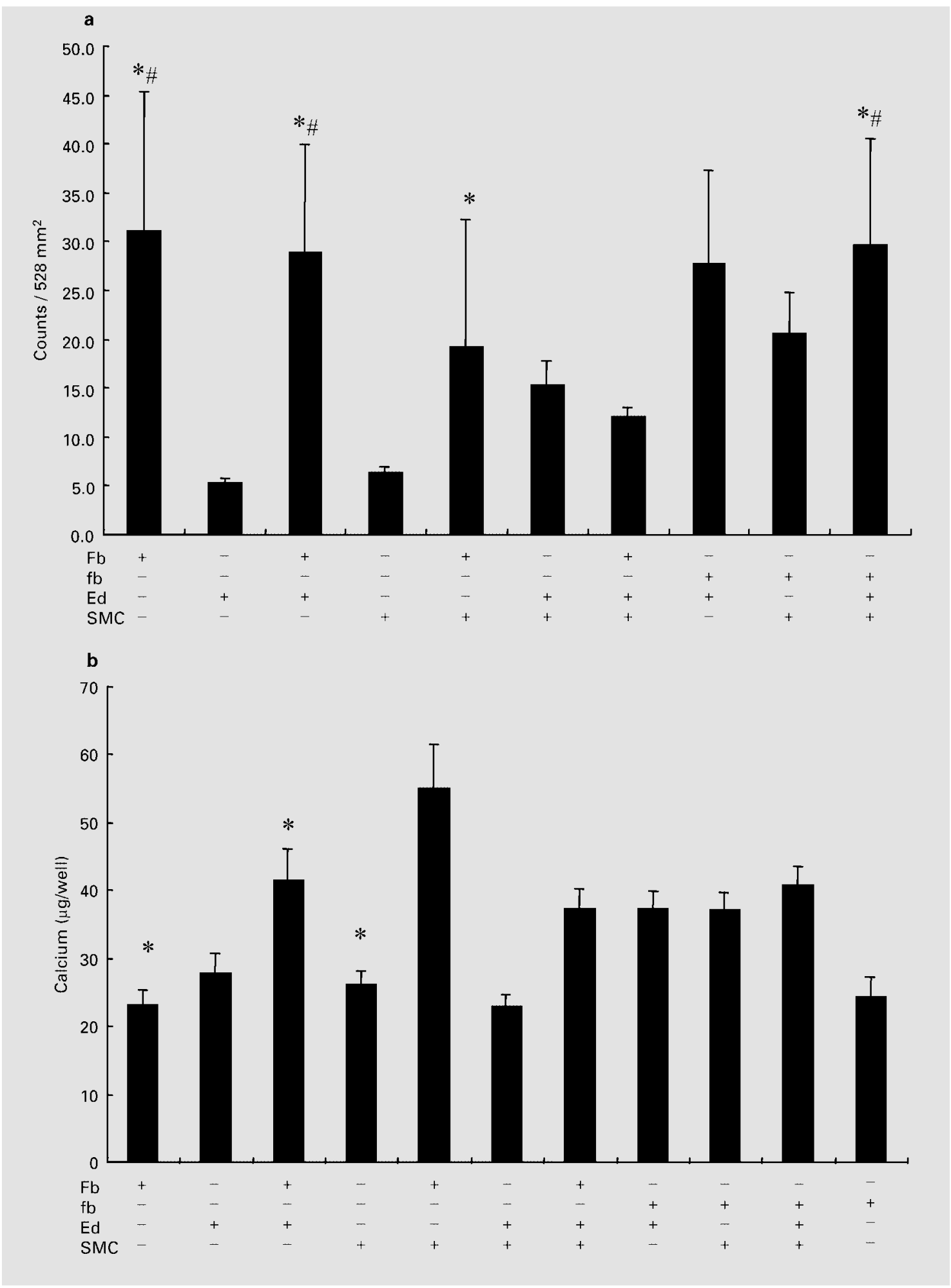

Fig. 2. Effects of cell populations. Fb, Ed and SMC or their mixtures were cultured in growth medium for 10 days. A matrix was obtained by freezing and thawing of $\mathrm{Fb}$ in hypotonic $(10 \mathrm{~m} M$ phosphate buffer, $27 \mathrm{mosm} / \mathrm{kg}$ ) solution $(\mathrm{Fb})$. Then the cell, Ed and/or SMC was seeded upon and maintained in growth medium for 10 days. a Num- bers of depositions. Each column represents the mean \pm SE of three dishes. ${ }^{*} \mathrm{p}<0.05$ compared to Ed. ${ }^{*} \mathrm{p}<0.05$ compared to SMC. b The calcium contents are expressed as means \pm SE of 6 to 14 dishes. ${ }^{*} \mathrm{p}<$ 0.05 compared to SMC+Ed. 


\section{Results}

\section{Calcium Deposition}

Figure 1 shows the deposition of calcium crystals on $\mathrm{Fb}$ in culture. Calcium crystals were seen as brown depositions on the dish. The size of the deposition varied from $20 \mu \mathrm{m}$ (fig. 1a) to $150 \mu \mathrm{m}$ (fig. 1b). We simply counted the number of depositions larger than $20 \mu \mathrm{m}$. The numbers of depositions in dishes containing $\mathrm{Fb}, \mathrm{Fb}+\mathrm{Ed}, \mathrm{Fb}+\mathrm{SMC}$ and $\mathrm{Fb}+\mathrm{Ed}+\mathrm{SMC}$ were significantly greater than that in a dish containing only Ed (fig. 2a). The numbers of depositions in dishes containing $\mathrm{Fb}, \mathrm{Fb}+\mathrm{Ed}$, and $\mathrm{Fb}+\mathrm{Ed}+\mathrm{SMC}$ were significantly greater than that in a dish containing only SMC (fig. 2a).

\section{Calcium Content}

Calcium content was measured and compared to that determined by VK. The calcium contents in dishes containing $\mathrm{Fb}, \mathrm{Fb}+\mathrm{Ed}$, and $\mathrm{SMC}$ were significantly higher than that in a dish containing SMC+Ed (fig. 2b). Therefore, we next changed the phosphate and calcium concentrations, added $\beta-\mathrm{GP}$, using $\mathrm{Fb}+\mathrm{SMC}$. We measured the deposition and calcium content. Figure 3 shows the deposition in high-phosphate medium (fig. 3a) and the calcium content in a medium to which $\beta-G P$ had been added (fig. 3b). The high-phosphate medium did not increase the deposition or content of calcium compared to those in the normal $1 \mathrm{~m} M$ phosphate medium. The deposition and content of calcium were also not increased by the addition of $\beta-\mathrm{GP}$, nor were they increased by a combination of $\beta$-GP in high-phosphate medium.

\section{Effect of Serum from Hemodialysis (HD) Patients on}

\section{Calcium Deposition Using the Fb+SMC}

We examined the effect of serum from HD patients on calcium deposition using the $\mathrm{Fb}+\mathrm{SMC}$. Figure 4 shows the effects of serum from normal controls and HD patients on calcium deposition and calcium content. There were no differences between the effects of non-HD serum, pre-HD serum and post-HD serum on calcium deposition count (fig. 4a) and calcium content (fig. 4b).

\section{Discussion}

We have designed these experiments to reproduce an in vitro calcification model following the previous study [14]. Surprisingly, SMC alone did not promote calcification, as determined by counting the number of deposits and measuring the calcium mineral content. The results

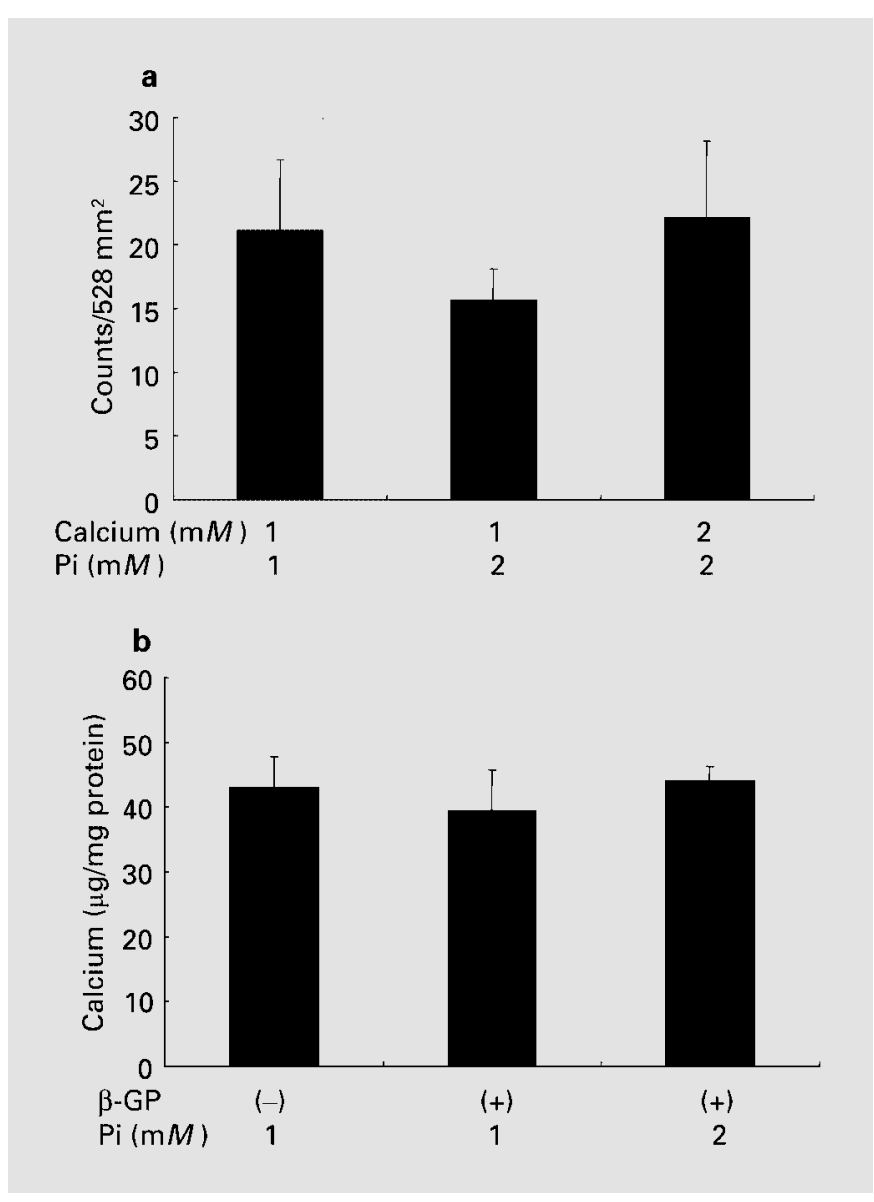

Fig. 3. Effects of high phosphate concentration (a) and $\beta$-glycerophosphate ( $\beta-G P)$ (b) on the deposition of calcium and on calcium content with $\mathrm{Fb}+\mathrm{SMC}$. Each column represents the mean $\pm \mathrm{SE}$ of 10 dishes.

of calcium deposition suggested that the presence of $\mathrm{Fb}$ in the mixture of cells is important and that a matrix of $\mathrm{Fb}$ rather than living $\mathrm{Fb}$ itself plays an essential role in the enhancement of calcium deposition (fig. $2 a$ ). The results with calcium content of $\mathrm{Fb}$ alone support the hypothesis that existence of $\mathrm{Fb}$ involves vascular calcification.

We used commercially available normal human cells from the aorta for the cultures. In contrast, primary cultures from the aorta after enzymatic digestion treatment were used in previous studies. Though we did not detect the existence of $\mathrm{Fb}$ in $\mathrm{SMC}$, primary cultures may contain some degree of $\mathrm{Fb}$ among the cultured SMC.

We did not clarify functional involvement of $\mathrm{Fb}$ in vascular calcification. There are many reports about matrix vesicle calcification $[17,18]$. In these, we could observe matrix vesicles and collagen have an important role to 
Fig. 4. Effects of sera from normal controls and hemodialysis (HD) patients on calcium deposition (a) and calcium content (b). Each column represents the mean $\pm \mathrm{SE}$.

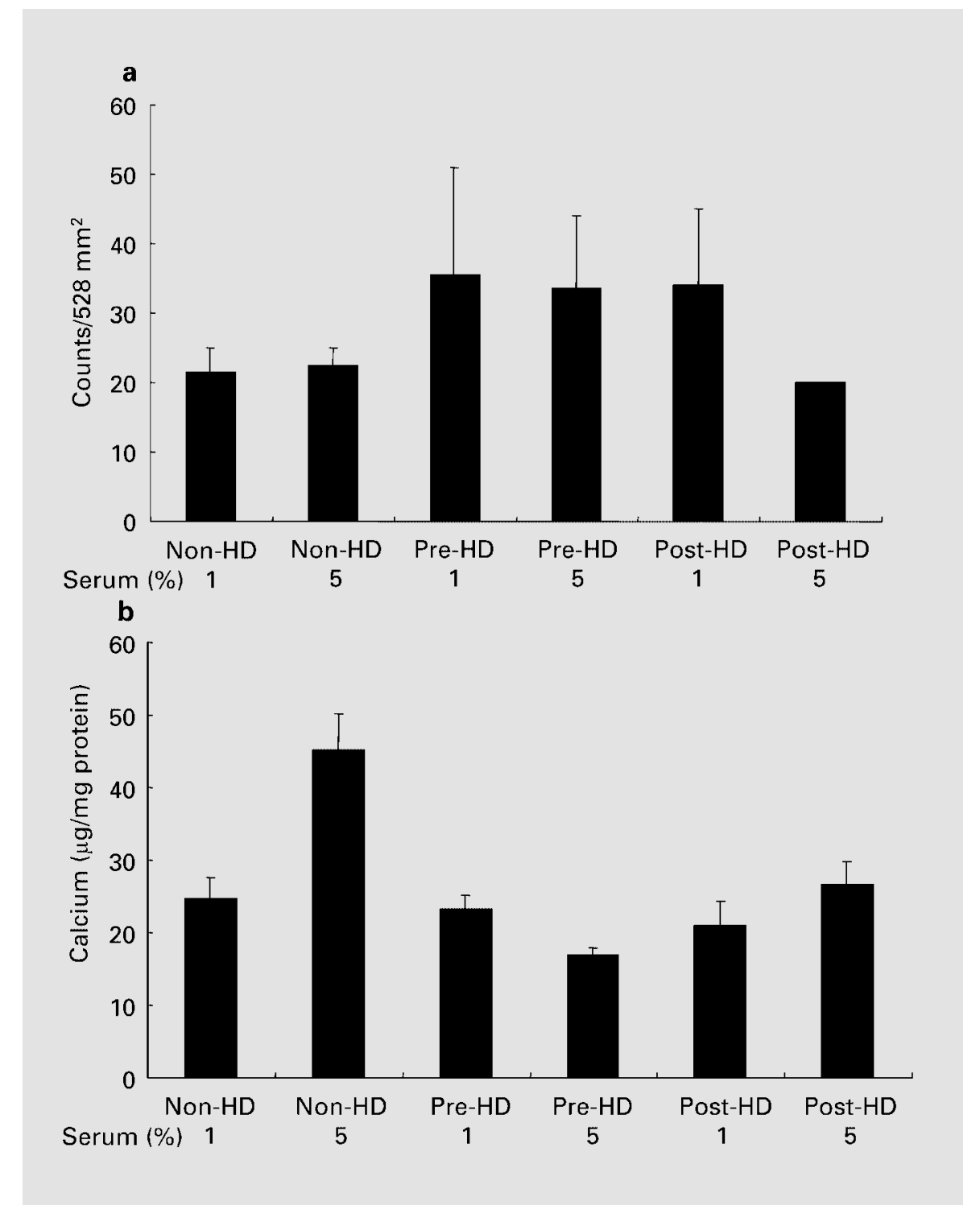

play in the mineralization cascade. But it is not clear that $\mathrm{Fb}$ has the ability to produce matrix more than other cell types and that the more matrix production from culture cells tends to form more increased calcification. Our findings indicate that the existence of $\mathrm{Fb}$ contributes vascular calcification exaggeration.

It is reported that osteopontin associates with ectopic calcification in atherosclerotic plaques. Ashizawa et al. [19] reported the expression of osteopontin protein in rat $\mathrm{Fb}$. Though we did not examine expression levels of osteopontin mRNA or protein in our experimental system, osteopontin would be an important gene to form calcium deposition.
In a previous study, a significant deposition of calcium crystals was observed on human SMC in a medium containing $2 \mathrm{~m} M$ phosphate until the 6th day of culture. However, no deposition of calcium crystals was observed on human SMC in a medium containing $2 \mathrm{~m} M$ phosphate until the 10th day of culture. In cultured bovine SMC, calcification was accelerated by $\beta$-GP [15]. But using commercially available human cells, calcification was not accelerated by $\beta$-GP.

An enhancement of calcification by $\beta$-GP as well as by high phosphate condition was not observed here, in opposition to the previous studies $[14,15]$. A series of their experiments suggest that high phosphate media stimu- 
lates $\beta$-GP production leading to calcification in cultured SMC. However, it seems controversial that soluble factors may play a dominant role in vascular calcification.

There are many reports suggesting that $\beta$-GP plays an important role in calcium mineralization. However, mineralization by $\mathrm{Ca} \times \mathrm{Pi} / \beta-\mathrm{GP}$ occurred in cartilage tissue, requiring type I collagen and fibroblast [20]. In contrast, no report except one can reproduce mineralization with $\beta-G P$ in culture of nonosteogenic cells [15]. Nonosteogenic cell lines can enhance mineral deposition in the absence of $\beta$-GP [21]. They suggest that the cells could promote pathologic mineralization by possessing alkaline phosphatase on the cell surface. In clinical background, $\mathrm{Ca} \times$ $P$ product is believed to play a major role in metastatic calcification involving vasculature. Although soft tissues are mineralized chemically, vascular mineralization is an active and complex process including atheosclerosis or many pathologic undermining [22]. The typical histopathologic finding of vascular calcification is microvascu- lar calcification with endovascular fibrosis [23]. Therefore, interaction of matrix rather than a simple soluble factor(s) may be important for the vascular calcification. In the present study with patient serum, we used 1 and $5 \%$ serum. We also made $10 \%$ serum containing media and found that the cells were damaged before the detection of calcification. Thus, soluble factor(s) alone did not lead the vascular cells to be mineralized in vitro thus far. In other words, sera from patients suffering from severe metastatic calcification may reveal bad influence on our cultures (data not shown). Finding of the factors of toxins in sera and analysis should be done in a future study.

In summary, we have shown that the existence of $\mathrm{Fb}$ precedes calcium deposition in vitro and the existence of SMC in culture or incubation with high-phosphate media, $\beta$-GP or sera of HD patients was not involved with calcium deposition. Therefore, what remains to be tested is to determine mechanisms in our experimental system.

\section{References}

1 Kurihara S, Suga M: Risk factors on renal osteodystrophy and metastatic calcification in patients with long-term dialysis. Rinshyou Touseki 2000;16:1011-1019.

2 Blumenthal HT, Lansing AI, Wheeler PA: Calcification of the media of the human aorta and its relation to intimal arteriosclerosis, aging and disease. Am J Pathol 1944;20:665-687.

3 Yu SY: Calcification processes in atherosclerosis. Adv Exp Med Biol 1974;43:403-425.

4 Moon JY: Factors affecting arterial calcification associated with atherosclerosis. Atherosclerosis 1972;16:119-126.

5 Boström K, Watson KE, Horn S, Wortham C, Herman IM, Demer LL: Bone morphogenetic protein expression in human atherosclerotic lesions. J Clin Invest 1993;91:1800-1809.

6 Shanahan CM, Cary NRB, Metcalfe JC, Weissberg PL: High expression of genes for calcification-regulating proteins in human atherosclerotic plaques. J Clin Invest 1994;93:23932402.

7 Fitzpatrick LA, Severson A, Edwards WD, Ingram RT: Diffuse calcification in human coronary arteries: Association of osteopontin with atherosclerosis. J Clin Invest 1994;94:15971604.

8 Shanahan CM, Proudfoot D, Tyson KL, Cary NRB, Edmonds M, Weissberg PL: Expression of mineralisation-regulating proteins in association with human vascular calcification. Z Kardiol 2000;89(suppl 2):63-68.
9 Nakayama T, Ohtsuru A, Enomoto H, Ozeki S, Shibata Y, Yokota T, Nobuyoshi M, Ito M, Sekine I, Yamasita S: Coronary atherosclerotic smooth muscle cells overexpress human parathyroid hormone-related peptides. Biochem Biophys Res Commun 1994;200:1028-1035.

10 Jono S, Nishizawa Y, Shioi A, Mori H: 1,25Dihydroxyvitamin $\mathrm{D}_{3}$ increases in vitro vascular calcification by modulating secretion of endogenous parathyroid hormone-related peptide. Circulation 1998;98:1302-1306.

11 Smith LL, Johnson BH: Biological activities of oxysterols. Free Rad Biol Med 1989;7:285332.

12 Hodis HN, Crawford DW, Sevanian A: Cholesterol feeding increases plasma and aortic tissue cholesterol oxide levels in parallel: Further evidence for the role of cholesterol oxidation in atherosclerosis. Atherosclerosis 1991;89:117126.

13 Shanahan CM, Proudfoot D, Tyson KL, Cary NR, Edmonds M, Weissberg PL: Expression of mineralisation-regulating proteins in association with human vascular calcification. Z Kardiol 2000;89(suppl 2):63-68.

14 Jono S, McKee MD, Murry CE, Shioi A, Nishizawa Y, Mori K, Morii H, Giachelli CM: Phosphate regulation of vascular smooth muscle cell calcification. Circ Res 2000;87:e10-e17.

15 Shioi A, Nishizawa Y, Jono S, Koyama H, Hosoi M, Morii $\mathrm{H}$ : $\beta$-Glycerophosphate accelerates calcification in cultured bovine vascular smooth muscle cells. Arterioscler Thromb Vasc Biol 1995;15:2003-2009.

16 Gitelman HJ: An improved automated procedure for determination of calcium in biological specimens. Anal Biochem 1967;18:521-531.
17 Anderson HC: Molecular biology of matrix vesicles. Clin Orthop 1995;314:266-280.

18 Kim KM: Matrix vesicle calcification of rat aorta millipore chambers. Met Bone Dis Rel Res 1978;1:213-217.

19 Ashizawa N, Kristof G, Do YS, Nunohiro T, Giachelli CM, Meehan WP, Tuan T, Hsueh WA: Osteopontin is produced by rat cardiac fibroblasts and mediates A-induced DNA synthesis and collagen gel contraction. J Clin Invest 1996;98:2218-2227.

20 Boskey AL, Stiner D, Binderman I, Doty SB: Type I collagen influences cartilage calcification: An immunoblocking study in differentiating chick limb-bud mesenchymal cell cultures. The Hospital for Special Surgery, New York, New York 10021, USA. J Cell Biochem 2000; 79:89-102.

21 Hui M, Li SQ, Holmyard D, Cheng P: Stable transfection of nonosteogenic cell lines with tissue nonspecific alkaline phosphatase enhances mineral deposition both in the presence and absence of beta-glycerophosphate: Possible role for alkaline phosphatase in pathological mineralization. Calcif Tissue Int 1997;60:467-472.

22 Yin T, Linda LD: Recent advances in multifactorial regulation of vascular calcification. Curr Opin Lipidol 2001;12:555-560.

23 Schwarz G, Laukhuf F, Bittinger F, Knop J, Saloga J: Calciphylaxis: Ischemic tissue necrosis in chronic renal failure. Case report and review of the literature. Hautarzt 2000;51:3640 . 